\title{
Molecular characterization and combined genotype association study of bovine cluster of differentiation 14 gene with clinical mastitis in crossbred dairy cattle
}

\author{
A. Sakthivel Selvan, I. D. Gupta, A. Verma, M. V. Chaudhari and A. Magotra \\ Molecular Genetics Laboratory, Dairy Cattle Breeding Division, National Dairy Research Institute, Karnal, Haryana, India. \\ Corresponding author: I. D. Gupta, e-mail: idgupta1959@gmail.com, \\ ASS: drasakthivel1987@gmail.com, AV: archana.ndri@gmail.com, MVC: mvet99@gmail.com, \\ AM: ankitoms@gmail.com \\ Received: 18-02-2016, Accepted: 25-05-2016, Published online: 01-07-2016
}

doi: 10.14202/vetworld.2016.680-684 How to cite this article: Selvan AS, Gupta ID, Verma A, Chaudhari MV, Magotra A (2016) Molecular characterization and combined genotype association study of bovine cluster of differentiation 14 gene with clinical mastitis in crossbred dairy cattle, Veterinary World, 9(7): 680-684.

\begin{abstract}
Aim: The present study was undertaken with the objectives to characterize and to analyze combined genotypes of cluster of differentiation 14 (CD14) gene to explore its association with clinical mastitis in Karan Fries (KF) cows maintained in the National Dairy Research Institute herd, Karnal.

Materials and Methods: Genomic DNA was extracted using blood of randomly selected 94 KF lactating cattle by phenolchloroform method. After checking its quality and quantity, polymerase chain reaction (PCR) was carried out using six sets of reported gene-specific primers to amplify complete KF CD14 gene. The forward and reverse sequences for each PCR fragments were assembled to form complete sequence for the respective region of KF CD14 gene. The multiple sequence alignments of the edited sequence with the corresponding reference with reported Bos taurus sequence (EU148610.1) were performed with ClustalW software to identify single nucleotide polymorphisms (SNPs). Basic Local Alignment Search Tool analysis was performed to compare the sequence identity of KF CD14 gene with other species. The restriction fragment length polymorphism (RFLP) analysis was carried out in all KF cows using Helicobacter pylori $188 I$ (Hpy188I) (contig 2) and Haemophilus influenzae I (HinfI) (contig 4) restriction enzyme (RE). Cows were assigned genotypes obtained by PCRRFLP analysis, and association study was done using Chi-square $\left(\chi^{2}\right)$ test. The genotypes of both contigs (loci) number 2 and 4 were combined with respect to each animal to construct combined genotype patterns.

Results: Two types of sequences of KF were obtained: One with 2630 bp having one insertion at 616 nucleotide (nt) position and one deletion at $1117 \mathrm{nt}$ position, and the another sequence was of 2629 bp having only one deletion at $615 \mathrm{nt}$ position. ClustalW, multiple alignments of KF CD14 gene sequence with $B$. taurus cattle sequence (EU148610.1), revealed $24 \mathrm{nt}$ changes (SNPs). Cows were also screened using PCR-RFLP with Hpy188I (contig 2) and HinfI (contig 4) RE, which revealed three genotypes each that differed significantly regarding mastitis incidence. The maximum possible combination of these two loci shown nine combined genotype patterns and it was observed only eight combined genotypes out of nine: AACC, AACD, AADD, ABCD, ABDD, BBCC, BBCD, and BBDD. The combined genotype ABCC was not observed in the studied population of KF cows. Out of 94 animals, AACD combined genotype animals (10.63\%) were found to be not affected with mastitis, and ABDD combined genotyped animals was observed having the highest mastitis incidence of $15.96 \%$.
\end{abstract}

Conclusion: AACD typed cows were found to be least susceptible to mastitis incidence as compared to other combined genotypes.

Keywords: cluster of differentiation 14, combined genotypes, Helicobacter pylori 188I, Haemophilus influenzae I, mastitis, single nucleotide polymorphisms.

\section{Introduction}

In India, out of total milk production (132.4 MT), $45 \%$ milk (59.80 MT) is contributed by cattle, whereas out of total cattle milk production more than half (32.3 MT) is contributed by crossbred cattle [1]. The prevalence of bovine mastitis ranged from $29.34 \%$ to $78.54 \%$ in cows [2-4], and in the last five decades,

Copyright: Selvan, et al. Open Access. This article is distributed under the terms of the Creative Commons Attribution 4.0 International License (http://creativecommons.org/licenses/by/4.0/), which permits unrestricted use, distribution, and reproduction in any medium, provided you give appropriate credit to the original author(s) and the source, provide a link to the Creative Commons license, and indicate if changes were made. The Creative Commons Public Domain Dedication waiver (http://creativecommons.org/ publicdomain/zero/1.0/) applies to the data made available in this article, unless otherwise stated. economic losses due to mastitis have increased from 52.9 crores per annum in 1963 [5] to 7165.51 crores per annum in 2012 [6].

There is sizeable evidence that suggests resistance to non-infectious diseases such as bovine leukocyte adhesion deficiency [7], bovine chondrodysplastic dwarfism [8], and dermatophilosis [9] and infectious diseases such as tuberculosis, salmonellosis [10], Jhone's disease [11], brucellosis [12], bovine leukemia virus infection [13], foot and mouth disease [14], and mastitis [15] have genetic basis. Therefore, present efforts are directed toward approaches such as identification of resistance genes, quantitative trait loci, and markers for such diseases so that disease can be detected at an early stage or a disease-resistant animal 
can be selected for further breeding [16]. There are a number of reports for candidate gene association with mastitis in Bos taurus [17-21] and also for Bos indicus animals $[22,23]$.

Cluster of differentiation 14 (CD14) is a $55-\mathrm{k}$ Dalton glycosyl phosphatidylinositol-anchored surface glycoprotein that is expressed mainly on monocytes and macrophages, and weakly on polymorphonuclear neutrophils surface [24]. It also acts as opsonin receptor, thereby helps in recognition and destruction of invading agents such as bacteria. Because of this role, as suggested by Ogorevc et al. [20,25], CD14 gene is one of the excellent candidates for mastitis in cattle. Ibeagha-Awemu et al. [19] and Pal et al. [26] characterized CD14 gene in Canadian Holstein and Jersey and Vrindavani Crossbred cattle breeds, respectively, while Kumar et al. [27] found an association between genetic variants of CD14 gene with mastitis incidence in Sahiwal (B. indicus) cattle. However, there is no report on CD14 gene characterization, single nucleotide polymorphisms (SNPs) detection, and combined genotype study in Karan Fries (KF) cattle (B. indicus $\times$ B. taurus) which is one of the important crossbred cattle in India. Therefore, a study was planned to characterize and identify SNPs in complete $\mathrm{CD} 14$ gene and explore the possible association between genetic variants of CD14 gene in KF cattle (B. indicus $\times B$. taurus) with clinical mastitis using combined genotyping.

\section{Materials and Methods}

Ethical approval

The experiment was approved by Institutional Animal Ethics Committee.

\section{PCR-RFLP analysis}

Blood samples were collected from randomly selected $94 \mathrm{KF}$ cows maintained at cattle yard of National Dairy Research Institute, Karnal. Cows with history of incidences of clinical mastitis (affected $\geq$ once) and also non-affected cows were selected. Genomic DNA isolation was done by phenol-chloroform method as described by Sambrook and Russell [28] with minor modifications. Quality of genomic DNA was checked on $0.8 \%$ agarose gel electrophoresis. Quality and quantity of DNA were also estimated by nanodrop spectrophotometer method.

Six sets of forward and reverse gene-specific primers reported by Ibeagha-Awemu et al. [19] and Kumar et al. [27] were used to amplify complete KF CD14 gene. Primers were synthesized and procured from M/s. Eurofins Genomics India Pvt., Ltd., Bengaluru. The sequence of primers, their respective nucleotide numbers, target region, and amplicon sizes are given in Table-1.

The polymerase chain reaction (PCR) mixture was incubated in thermal cycler initially at $94^{\circ} \mathrm{C}$ for 2 min followed by 34 cycles of $94^{\circ} \mathrm{C}$ for $30 \mathrm{~s}, 60^{\circ} \mathrm{C}$ (contig $1,4,5,6$ ) or $59^{\circ} \mathrm{C}$ (contig 2, 3) for $30 \mathrm{~s}, 72^{\circ} \mathrm{C}$ for $40 \mathrm{~s}$, and a final extension of $72^{\circ} \mathrm{C}$ for $10 \mathrm{~min}$. The amplified PCR products were checked on 2\% agarose gel to ensure amplification of target region. Amplified PCR products from all sets of primers were custom sequenced from both ends (5' and 3' ends) by M/s. SciGenom Labs Pvt., Ltd. Nucleotide sequences were visualized and edited using BioEdit software. The forward and reverse sequences for each PCR fragments were assembled to form a complete sequence for the respective region of KF CD14 gene. The multiple sequence alignments of the edited sequence with corresponding reference with reported $B$. taurus sequence (EU148610.1) were performed with ClustalW software to identify SNPs. Basic Local Alignment Search Tool (BLAST) analysis was performed to compare the sequence identity of KF CD14 gene with other species.

The restriction fragment length polymorphism (RFLP) analysis was carried out in all KF cows using Helicobacter pylori 188I (Hpy188I) (contig 2) and Haemophilus influenzae I (HinfI) (contig 4) restriction enzyme (RE). PCR amplified CD14 gene products of each animal were digested with $0.4 \mu 1$ each of Hpy $188 \mathrm{I}$ and HinfI RE at $37^{\circ} \mathrm{C}$ for $16 \mathrm{~h}$. Fragments of $\mathrm{RE}$ digestion were separated on $2.5 \%$ agarose gel and photographed using gel documentation system. Cows were grouped as mastitis affected and not affected and were assigned genotypes obtained by PCR-RFLP analysis.

Table-1: Sequence of the primers referred for amplification of complete CD14 gene in KF cattle.

\begin{tabular}{|c|c|c|c|c|c|}
\hline \multirow{2}{*}{$\begin{array}{l}\text { Primer set } \\
1\end{array}$} & \multicolumn{2}{|c|}{ Sequence ( $\left.5^{\prime}-3^{\prime}\right)$} & \multirow{3}{*}{$\begin{array}{c}\begin{array}{c}\text { Number of } \\
\text { base pairs }\end{array} \\
22 \\
22\end{array}$} & \multirow{2}{*}{$\begin{array}{c}\text { Target region } \\
-404-307\end{array}$} & \multirow{2}{*}{$\begin{array}{c}\begin{array}{c}\text { Amplicon } \\
\text { size (bp) }\end{array} \\
711\end{array}$} \\
\hline & $\mathrm{F}$ & АТTACСТTСТTСTGСАССТССА & & & \\
\hline & $\mathrm{R}$ & GAAAGTGAAGTCGCTCAGTCCT & & (Promoter) & \\
\hline \multirow[t]{2}{*}{2} & $\mathrm{~F}$ & ACACACCTGGAGAAGGCAA & 20 & $177-729$ & 553 \\
\hline & $\mathrm{R}$ & TCCAAGGGCTAGTTCCAG AG & 20 & (Promoter*) & \\
\hline \multirow[t]{2}{*}{3} & $\mathrm{~F}$ & CAATTCCTGGTCAGGGAACTAA & 22 & $561-1173$ & 613 \\
\hline & $\mathrm{R}$ & GGCAGCCTCTGAGAGTTTATGT & 22 & (Promoter*) & \\
\hline \multirow[t]{2}{*}{4} & $\mathrm{~F}$ & СTTCCTGTTATAGCCCCTTTCC & 22 & $1012-1843$ & 832 \\
\hline & $\mathrm{R}$ & CACGATACGTTACGGAGACTGA & 22 & (Promoter*, Exon-1, Intron, Exon-2*) & \\
\hline \multirow[t]{2}{*}{5} & $\mathrm{~F}$ & GGGTACTCTCGTCTCAAGGAAC & 22 & $1722-2546$ & 825 \\
\hline & $\mathrm{R}$ & CTGAGCCAATTCATTCСTCTTC & 22 & $($ Exon-2*) & \\
\hline \multirow[t]{2}{*}{6} & $\mathrm{~F}$ & АCCTGACTCTGGACGGAAATC & 21 & $2347-3093$ & 747 \\
\hline & $\mathrm{R}$ & TAC AGGAGAGCAACCCTGAAA & 21 & (Exon-2*) & \\
\hline
\end{tabular}

*Overlapping and partial. CD14=Cluster of differentiation 14, KF=Karan Fries

Veterinary World, EISSN: 2231-0916 


\section{Statistical analysis}

Chi-square $\left(\chi^{2}\right)$ test was performed to test whether gene variants were independent. Further, restriction fragments were utilized to construct combined genotypes.

\section{Results and Discussion}

Two types of sequences of KF were obtained: One with 2630 bp having one insertion at 616 nucleotide (nt) position and one deletion at $1117 \mathrm{nt}$ position, and the another sequence was of $2629 \mathrm{bp}$ having only one deletion at $615 \mathrm{nt}$ position. ClustalW, multiple alignments of KF CD14 gene sequence with B. taurus cattle sequence (EU148610.1) reported by Ibeagha-Awemu et al. [19], revealed 24 nt changes (SNPs) (Figure-1 and Table-2). Out of 24 SNPs compared with $B$. taurus, 13 SNPs were transition type of mutation, 8 SNPs were transversion type of mutation, 2 SNPs were deletion type of mutation, and 1 SNP was insertion type of mutation. 5 SNPs were in coding region resulting in synonyms amino acid change. Table-3 depicts comparative nucleotide sequences of Karan Fries (KF), Bos taurus and Sahiwal cattle showing nucleotide change of Guanine to adenine at position 2601. Crossbreeding and, species and breed variation of inheritance between KF (Tharparkar $[B$. indicus $] \times$ Holstein Friesian [B. taurus]), B. taurus may have been caused SNPs in KF cattle compared to reported CD14 gene sequence of $B$. taurus [19]. In BLAST analysis, KF cattle showed $86-99 \%$ sequence identity with several domestic animals (Table-4).

PCR-RFLP analysis revealed two polymorphic patterns in contig 2 and 4 . Hpy $188 I$ had cutting site in contig 2 that exhibited three genotypes (band patterns) such as AA (305 and $248 \mathrm{bp}), \mathrm{AB}(305,248,138$ and $110 \mathrm{bp}$ ), and BB (305, 248, 138, and $110 \mathrm{bp})$ genotypes. HinfI had cutting site in contig 4 that exhibited three genotypes (band patterns) such as CC $(377,272$, and $183 \mathrm{bp}), \mathrm{CD}(377,272,225,183$, and $47 \mathrm{bp})$, and DD $(377,225,183$, and $47 \mathrm{bp})$ genotypes. So, there were three genotypes in contig $2(\mathrm{AA}, \mathrm{AB}$, and $\mathrm{BB})$ and three genotypes in contig 4 (CC, $\mathrm{CD}$, and DD).

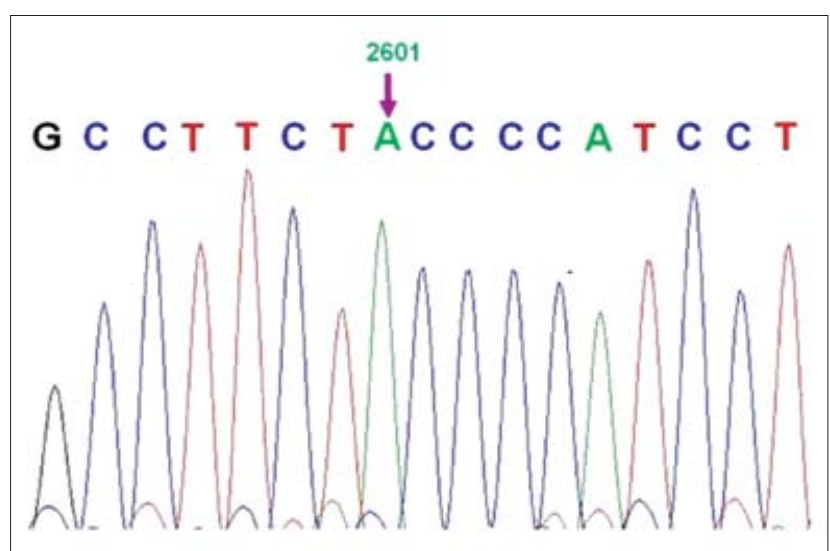

Figure-1: Chromatogram showing nucleotide change at position 2601 ( $G>A)$.
Chi-square $\left(\chi^{2}\right)$ analysis revealed that all the genotypes of KF cattle differed significantly from each other regarding mastitis incidence. The genotypes of both contigs (loci) number 2 and 4 were combined with respect to each animal to construct combined genotype patterns. If animal number "1" was having genotype "AA" at locus number 2 , whereas genotype "CD" at locus number 4 then that animal will have combined genotype pattern "AACD." In this way, combined genotypes were constructed. The maximum possible combination of these two loci shown

Table-2: Summary of nucleotide changes in CD14 gene of $\mathrm{KF}$ as compared to B. taurus (EU148610.1).

\begin{tabular}{lcll}
\hline Region & Position & KF & $\begin{array}{l}\text { B. taurus (I beagha } \\
\text { et al., 2008) }\end{array}$ \\
\hline Promoter & 269 & $\mathrm{~A}$ & $\mathrm{G}$ \\
& 271 & $\mathrm{C}$ & $\mathrm{T}$ \\
& 273 & $\mathrm{~A}$ & $\mathrm{C}$ \\
& 276 & $\mathrm{C}$ & $\mathrm{G}$ \\
& 277 & $\mathrm{~A}$ & $\mathrm{G}$ \\
& 281 & $\mathrm{C}$ & $\mathrm{T}$ \\
& 357 & $\mathrm{~T}$ & $\mathrm{G}$ \\
& 418 & $\mathrm{C}$ & $\mathrm{A}$ \\
& 431 & $\mathrm{~A}$ & $\mathrm{G}$ \\
& 458 & $\mathrm{G}$ & $\mathrm{C}$ \\
& 615 & $\mathrm{Deletion}$ & $\mathrm{A}$ \\
& 616 & $\mathrm{~A}$ (insertion) & - \\
Exon 1 & 778 & $\mathrm{~T}$ & $\mathrm{C}$ \\
& 922 & $\mathrm{~A}$ & $\mathrm{G}$ \\
Intron & 1117 & $\mathrm{Deletion}$ & $\mathrm{T}$ \\
& 1239 & $\mathrm{G}$ & $\mathrm{T}$ \\
Exon 2 & 1291 & $\mathrm{C}$ & $\mathrm{T}$ \\
& 1359 & $\mathrm{C}$ & $\mathrm{G}$ \\
Exon 2, & 1361 & $\mathrm{~A}$ & $\mathrm{G}$ \\
3'UTR & 1811 & $\mathrm{~A}$ & $\mathrm{G}$ \\
& 1909 & $\mathrm{G}$ & $\mathrm{A}$ \\
\hline B. taurus & 2276 & $\mathrm{~T}$ & $\mathrm{C}$ \\
& 2601 & $\mathrm{~A}$ & $\mathrm{G}$ \\
& 2621 & $\mathrm{G}$ & $\mathrm{T}$ \\
\hline
\end{tabular}

B. taurus $=$ Bos taurus, $C D 14=$ Cluster of differentiation 14 $\mathrm{KF}=$ Karan Fries

Table-3: Comparative nucleotide sequences of Karan Fries (KF), Bos taurus and Sahiwal cattle showing nucleotide change at position 2601 (G>A).

\begin{tabular}{lll}
\hline KF_2630 & GCCTTCTACCCCATCCT & 2610 \\
KF_2629 & GCCTTCTACCCCATCCT & 2610 \\
Bos taurus & GCCTTCTGCCCCATCCT & 2610 \\
Sahiwal & GCCTTCTGCCCCATCCT & 2610 \\
\hline
\end{tabular}

Table-4: Identity of CD14 gene of KF (B. indicus $\times$ Bos taurus) with other species.

\begin{tabular}{lll}
\hline Accession no. & Species & Homology (\%) \\
\hline EU148610.1 & B. taurus & 99 \\
DQ457089.1 & B. bubalis & 98 \\
NM_001077209.1 & O. aries & 97 \\
DQ457090.1 & C. hircus & 93 \\
AY753180.1 & S. scrofa & 86
\end{tabular}

B. taurus $=$ Bos taurus, B. bubalis $=$ Bubalus bubalis,

O. aries $=$ Ovis aries, $C$. hircus $=$ Capra hircus,

S. scrofa=Sus scrofa, CD14=Cluster of differentiation 14, $\mathrm{KF}=$ Karan Fries 
Table-5: Frequency of combined genotype of CD14 gene in KF cattle.

\begin{tabular}{|c|c|c|c|c|c|c|c|c|c|}
\hline \multirow{3}{*}{$\begin{array}{l}\text { Combined } \\
\text { genotype }\end{array}$} & \multirow{3}{*}{$\begin{array}{c}\text { Total } \\
\text { animals }\end{array}$} & \multicolumn{4}{|c|}{ Mastitis affected } & \multicolumn{4}{|c|}{ Mastitis not affected } \\
\hline & & \multirow{2}{*}{$\begin{array}{c}\text { Number } \\
\text { of } \\
\text { animals }\end{array}$} & \multicolumn{3}{|c|}{ Percentage } & \multirow{2}{*}{$\begin{array}{c}\text { Number } \\
\text { of } \\
\text { animals }\end{array}$} & \multicolumn{3}{|c|}{ Percentage } \\
\hline & & & $\begin{array}{c}\text { Within } \\
\text { each } \\
\text { genotype }\end{array}$ & $\begin{array}{l}\text { Among } \\
\text { mastitis } \\
\text { affected } \\
(n=59)\end{array}$ & $\begin{array}{c}\text { Within } \\
\text { herd } \\
(n=94)\end{array}$ & & $\begin{array}{c}\text { Within } \\
\text { each } \\
\text { genotype }\end{array}$ & $\begin{array}{c}\text { Among } \\
\text { mastitis not } \\
\text { affected } \\
(n=35)\end{array}$ & $\begin{array}{l}\text { Within herd } \\
(n=94)\end{array}$ \\
\hline AACC & 04 & 02 & 50.0 & 03.39 & 02.13 & 02 & 50.0 & 05.71 & 02.13 \\
\hline AACD & 20 & 10 & 50.0 & 16.94 & 10.63 & 10 & 50.0 & 28.57 & 10.63 \\
\hline AADD & 16 & 8 & 50.0 & 13.55 & 08.51 & 8 & 50.0 & 22.85 & 08.51 \\
\hline $\mathrm{ABCC}$ & \multicolumn{9}{|c|}{ Not observed } \\
\hline$A B C D$ & 10 & 9 & 90.0 & 15.25 & 09.57 & 1 & 10.0 & 02.85 & 01.06 \\
\hline ABDD & 21 & 15 & 71.4 & 25.42 & 15.96 & 6 & 28.57 & 17.14 & 06.38 \\
\hline BBCC & 03 & 1 & 33.3 & 01.69 & 01.06 & 2 & 66.66 & 05.71 & 02.12 \\
\hline $\mathrm{BBCD}$ & 06 & 6 & 100.0 & 10.16 & 06.38 & - & - & & \\
\hline BBDD & 14 & 8 & 57.1 & 13.55 & 08.51 & 6 & 42.85 & 17.14 & 06.38 \\
\hline Total & 94 & 59 & - & 100.00 & 62.77 & 35 & - & 100.00 & 37.23 \\
\hline
\end{tabular}

CD14 $=$ Cluster of differentiation $14, \mathrm{KF}=$ Karan Fries

nine combined genotype patterns, and it was observed only eight combined genotypes out of nine: AACC, $\mathrm{AACD}, \mathrm{AADD}, \mathrm{ABCD}, \mathrm{ABDD}, \mathrm{BBCC}, \mathrm{BBCD}$, and BBDD with 4, 20, 16, 10, 21, 3, 6, and 14 numbers of animals in each combined genotype, respectively (Table-5). The combined genotype ABCC was not observed in the studied population of KF cows.

\section{Association analysis of combined genotyped cows of CD14 gene with clinical mastitis}

In Table-5, out of the four animals of combined genotypes "AACC," 50\% animals were mastitis affected and $50 \%$ animals were mastitis not affected. Among 59 animals (mastitis affected) and 94 animals (total animals analyzed for combined genotype study), $3.39 \%$ and $2.13 \%$ animals, respectively, were of "AACC" combined genotype. Similarly, among 35 animals (mastitis not affected) and 94 animals (total animals analyzed for combined genotype study), $5.71 \%$ and $2.13 \%$ animals, respectively, were of "AACC" combined genotype.

Among 94 cows studied for combined genotype analysis, 59 were mastitis affected. When the frequencies of combined genotypes of CD14 gene, fragments in $\mathrm{KF}$ cows were analyzed within each genotype: $100 \%, 90 \%$, and $71.4 \%$ of animals in BBCD, ABCD, and ABDD genotype were observed having mastitis incidence, respectively. While among 59 mastitis affected KF cows, combined genotype ABDD was observed having the highest mastitis incidence (25.42\%), i.e., 15 out of 59 animals. Out of 59 cows, around $64 \%$, i.e., 38 cows with combined genotypes $\mathrm{ABCD}, \mathrm{ABDD}, \mathrm{BBCD}$, and $\mathrm{BBDD}$ were mastitis affected which is in accordance with previous reports by Selvan et al. [29] where cows with AB and BB genotypes and by Selvan et al. [30] where cows with $C D$ and DD genotypes were mastitis affected. Further, on comparison within herd (94 animals), combined genotype ABDD was observed having the highest mastitis incidence of $15.96 \%$. Similar comparison was done for non-mastitis affected animals (35 animals). Out of 94 animals, AACD combined genotype animals $(10.63 \%)$ were found to be not affected with mastitis (Table-5). Hence, it can be inferred that animals with ABDD genotypic combination are more susceptible to mastitis, and on the other hand, AACD typed animals are least susceptible to incidence of mastitis as compared to other combined genotypes.

\section{Conclusions}

It may be possible that cows with AACD combined genotype might have a higher percentage of leukocytes expressing CD14 molecules on their surface which may increase the speed of response to pathogen attack [31,32]. Further research will be needed to conclude the relationships among CD14 genotypes, combined genotypes, concentration of CD14 in mammary tissues, and clinical mastitis.

\section{Authors' Contributions}

IDG conceived and designed the work. ASS conducted experiment. ASS and MVC done analysis, association study and AM assisted in writing of the manuscript. IDG and AV helped in revision of the manuscript. All authors read and approved the final manuscript.

\section{Acknowledgments}

The authors are thankful to Head DCB Division, for providing necessary research facilities. The authors also thankful to the Director (NDRI) for financial assistance provided during the research work.

\section{Competing I nterests}

The authors declare that they have no competing interest.

\section{References}

1. BAHS. (2014) Basic Animal Husbandry Statistics. Government of India, Ministry of Agriculture, Department of Animal Husbandry, Dairying and Fishries, Krishi Bhawan, New Delhi.

2. Sharma, S.D. and Rai, P. (1977) Studies on the incidence 
of bovine mastitis in Uttar Pradesh. Indian. Vet. J., 54: 435-439.

3. Ebrahimi, A., Kheirabadi, K.H.P. and Nikookhah, F. (2007) Antimicrobial susceptibility of environmental bovine mastitis pathogen in west central Iran. Pak. J. Biol. Sci., 10: 3014-3016.

4. Sharma, N. and Maiti, S.K. (2010) Incidence, etiology and antibiogram of subclinical mastitis in cows in durg, Chhattisgarh. Indian J. Vet. Res., 19: 45-54.

5. Dhanda, M.R. and Sethi, M.S. (1962) Investigation of mastitis in India. ICAR Research, Series No. 35, New Delhi, India.

6. NDRI News Letter. (2012) 17(1). Available from: http:// www.ndri.res.in. Accessed on 15-01-2016.

7. Shuster, D.E., Kehrli, M.E.Jr., Ackermann, M.R. and Gilbert, R.O. (1992) Identification and prevalence of a genetic defect that causes leukocyte adhesion deficiency in Holstein cattle. Proc. Natl. Acad. Sci., 89: 9225-9229.

8. Takeda, H., Takami, M., Oguni, T., Tsuji, T., Yoneda, K., Sato, H., Ihara, N., Itoh, T., Kata, S.R. and Mishina, Y. (2002) Positional cloning of the gene LIMBIN responsible for bovine chondrodysplastic dwarfism. Proc. Natl. Acad. Sci., 99, 10549-10554.

9. Maillard, J.C., Berthier, D., Chantal, I., Thevenon, S. and Sidibe, I. (2003) Selection assisted by BoLA-DR/DQ haplotype against susceptibility to bovine dermatophilosis. Genet. Select. Evol., 35(1): S193-S200.

10. Qureshi, S., Larivière, L., Sebastiani, G., Clermont, S., Skamene, E., Gros, P. and Malo, D. (1996) A high-resolution map in the chromosomal region surrounding the LPS locus. Genomics, 31: 283-294.

11. Pinedo, P.J., Donovan, A., Rae, O. and DeLapaz, J. (2009) Association between paratuberculosis infection and general immune status in dairy cattle. In: Proceedings of the $10^{\text {th }}$ International Colloquium on Paratuberculosis. Vol. 1. p127.

12. Kumar, N., Mitra, A., Ganguly, I., Singh, R., Deb, S.M., Srivatsava, S.K. and Sharma, A. (2005) Lack of association of brucellosis resistance with (GT) (13) microsatellite allele at 3'UTR of NRAMP1 gene in Indian zebu (Bos indicus) and crossbred (Bos indicus X Bos taurus) cattle. Vet. Microbiol., 111: 139-143.

13. Juliarena, M.A., Poli, M., Ceriani, C., Sala, L., Rodríguez, E., Gutierrez, S., Dolcini, G., Odeon, A. and Esteban, E.N. (2009) Antibody response against three widespread bovine viruses is not impaired in Holstein cattle bovine leukocyte antigen (BoLA) DRB3.2 carrying alleles associated with bovine leukemia virus resistance. J. Dairy Sci., 92(1): 375-381.

14. Garcia-Briones, M.M., Russell, G.C., Oliver, R.A., Tami, C., Taboga, O., Carrillo, E., Palma, E.L., Sobrino, F. and Glass, E.J. (2000) Association of bovine DRB3 alleles with immune response to FMDV peptides and protection against viral challenge. Vaccine, 19: 1167-1171.

15. Beecher, C., Daly, M., Childs, S., Berry, D.P., Magee, D.A., McCarthy, T.V. and Giblin, L. (2010) Polymorphisms in bovine immune genes and their associations with somatic cell count and milk production in dairy cattle. BMC Genet., 11: 99-108.

16. Rainard, P. and Riollet, C. (2006) Innate immunity of the bovine mammary gland. Vet. Res., 37: 369-400.

17. Rupp, R., Hernandez, A. and Mallard, B.A. (2007)
Association of bovine leukocyte antigen (BoLA) DRB 3.2 with immune response, mastitis and production and type traits in Canadian Holsteins. J. Dairy Sci., 90: 1029-1038.

18. Wang, X., Xu, S., Xue, S., Ren, H. and Chen, J. (2007) Genetic polymorphism of TLR4 gene and correlation with mastitis in cattle. J. Genet. Genom., 34(5): 406-412.

19. Ibeagha-Awemu, E.M., Lee, J.W. and Ibeagha, A.E. (2008) Bovine CD14 gene characterization and relationship between polymorphisms and surface expression on monocytes and polymorphonuclear neutrophils. BMC Genet., 9: $50-60$.

20. Ogorevc, J., Kunej, T., Razpet, A. and Dovc, P. (2009) Database of cattle candidate genes and genetic markers for milk production and mastitis. Anim. Genet., 40: 832-851.

21. Yuan, Z., Chu, G., Dan, Y., Li, J., Zhang, L., Gao, X., Gao, H., Li, J., Xu, S. and Liu, Z. (2012) BRCA1: A new candidate gene for bovine mastitis and its association analysis between single nucleotide polymorphisms and milk somatic cell score. Mol. Biol. Rep., 39: 6625-6631.

22. Soumya, N.P., Gupta, I.D., Verma, A., Raja, K.N., Chauhan, I. and Chaudhari, M.V. (2013) Identification of CARD-15 gene polymorphism in Sahiwal cattle. Indian. $J$. Anim. Res., 47(1): 83-86.

23. Wakchaure, S.R., Gupta, I.D., Verma, A., Kumar, S.R. and Kumar, D. (2012) Study of toll like receptors 4 (TLR 4) gene in cattle: A review. Agric. Rev., 33(3): 220-225.

24. Antal-Szalmas, P., Van Strjp, J.A.G., Weersink, A.J.L., Verhoef, J. and Van Kessel, K.P.M. (1997) Quantitation of surface CD 14 on human monocytes and neutrophils. J. Leukoc. Biol., 61: 721-728.

25. Ogorevc, J., Kunej, T. and Dovc, P. (2008) An integrated map of cattle candidate genes for mastitis: A step forward to new genetic markers. Acta Agric. Slov., 2: 85-91.

26. Pal, A., Sharma, A., Bhattacharya, T.K., Chatterjee, P.N. and Chakravarty, A.K. (2011) Molecular characterization and SNP detection of CD14 gene of crossbred cattle. Mol. Biol. Int., DOI: 10.4061/2011/507346.

27. Kumar, V., Gupta, I.D., Verma, A., Kumar, S.R. and Chaudhari, M.V. (2014) CD14 gene polymorphism using $\mathrm{HINFl}$ restriction enzyme and its association with mastitis in Sahiwal cattle. Indian J. Anim. Res., 48(1): 11-13.

28. Sambrook, J. and Russell, D.W. (1989) Preparation and analysis of eukaryotic DNA. In: Molecular Cloning: A Laboratory Manual. $3^{\text {rd }}$ ed. Cold Spring Harbor Laboratory Press, New York. p6.1-6.62.

29. Selvan, A.S., Gupta, I.D., Verma, A., Chaudhari, M.V., Kanungo, S. and Kumar, S.R. (2014a) Characterization of promoter region of CD14 gene and association with clinical mastitis in Karan Fries cattle. Indian. J. Anim. Res., 48(6): 545-547.

30. Selvan, A.S., Gupta, I.D., Verma, A., Chaudhari, M.V. and Kumar, V. (2014b) Cluster of differentiation 14 gene polymorphism and its association with incidence of clinical mastitis in Karan fries cattle. Vet. World, 7(12): 1037-1040.

31. Paape, M.J., Shafer-Weaver, K., Capuco, A.V., Van Oostveldt, K. and Burvenich, C. (2000) Immune surveillance of mammary tissue by phagocytic cells. $A d v$. Exp. Med. Biol., 480: 259-277.

32. Akira, S., Uematsu, S. and Takeuchi, O. (2006) Pathogen recognition and innate immunity. Cell, 124: 783-801. 